HEMOGLOBIN

Vol. 28, No. 3, pp. 237-241, 2004

\title{
A C677T Methylenetetrahydrofolate Reductase (MTHFR) Polymorphism and G20210A Mutation in the Prothrombin Gene of Sickle Cell Anemia Patients from Northeast Brazil
}

\author{
Fábio David Couto, ${ }^{1}$ Wendell Vilas Boas, ${ }^{1}$ Isa Lyra, ${ }^{2,4}$ Ângela Zanette, ${ }^{4}$ \\ Marie France Dupuit, ${ }^{2}$ Mari Ney Tavares Almeida, ${ }^{2}$ \\ Mitermayer Galvão Reis, ${ }^{1}$ and Marilda Souza Gonçalves ${ }^{1,2, *}$ \\ ${ }^{1}$ Laboratório de Patologia e Biologia Molecular, Centro de Pesquisas Gonçalo Moniz, \\ Fundação Oswaldo Cruz (FIOCRUZ), Salvador-Bahia, Brasil \\ ${ }^{2}$ Universidade Federal da Bahia, Salvador-Bahia, Brasil \\ ${ }^{3}$ Complexo Pediátrico Professor Hosanah de Oliveira, Ambulatório de Hematologia \\ Pediátrica, Hospital Universitário Professor Edgar Santos da Universidade \\ Federal da Bahia, Canela, Salvador-Bahia, Brasil \\ ${ }^{4}$ Ambulatório de Hematologia, Fundação de Hematologia e Hemoterapia da Bahia \\ (HEMOBA), Salvador-Bahia, Brasil
}

\begin{abstract}
The C677T methylenetetrahydrofolate reductase (MTHFR) gene polymorphism and the G20210A mutation at the $3^{\prime}$ untranslated region ( $3^{\prime}$ UTR) of the prothrombin gene may be considered to be genetic risk factors that contribute to the clinical heterogeneity in sickle cell disease. The current study investigated a group of sickle cell (SS) patients from Salvador-Bahia, Northeast Brazil in order to determine the prevalence of these polymorphisms, using the polymerase chain reaction (PCR) and restriction fragment length polymorphim (RFLP) techniques. Out of 69 SS patients
\end{abstract}

\footnotetext{
*Correspondence: Dr. Marilda Souza Gonçalves, Laboratório de Patologia e Biologia Molecular, Centro de Pesquisas Gonçalo Moniz, Fundação Oswaldo Cruz (FIOCRUZ), Rua Waldemar Falcão 121, Brotas, Salvador-Bahia, CEP: 40.295-001, Brasil; Fax: +55-71-356-2155; E-mail: mari@ cpqgm.fiocruz.br.
} 


\begin{abstract}
diagnosed with the C677T MTHFR gene polymorphism, 13 (18.6\%) were heterozygous and four $(5.7 \%)$ homozygous. The G20210A mutation was not found in $50 \mathrm{SS}$ patients investigated. These results became important once the C677T MTHFR gene polymorphism was found to be an independent risk factor for vascular disease, a common clinical event in sickle cell disease.
\end{abstract}

Key Words: Methylenetetrahydrofolate reductase (MTHFR); Prothrombin gene; Sickle cell anemia; Salvador-Bahia, Brazil.

Sickle cell disease is one of the most common and complex genetic disorders found worldwide, mainly among people of African origin. The clinical heterogeneity of sickle cell disease is well documented and many genetic and environmental factors have been considered to influence its pathophysiology. $\alpha$-Thalassemia (thal), different $\beta^{\mathrm{S}}$-globin gene haplotypes, fetal hemoglobin $(\mathrm{Hb})$ levels, G6PD deficiency, cell hydration, nutritional and other environmental conditions, are intrinsic and extrinsic factors described as potential modifiers of the sickle cell clinical phenotype (1).

Prothrombin and methylenetetrahidrofolate reductase (MTHFR) are some of the target genes investigated in thromboembolism events in general and in sickle cell anemia patients $(2,3)$. Both these genetic polymorphisms are supposed to be involved in vascular alterations. They have been investigated in groups of individuals carrying other genetic risk factors for vascular disease, such as sickle cell anemia (4).

Bahia, a state located in northeast Brazil, shows an elevated racial admixture resulting in a pool of inherited genetic diseases (5). The heterozygous state of sickle cell disease ( $\mathrm{Hb} \mathrm{AS}$ ) reaches $14 \%$, and sickle cell anemia up to $1.6 \%$ in a group of Bahians of African descent (6). In this context, it is useful to investigate the prevalence of two genetic markers, the C677T MTHFR gene polymorphism and the G20210A mutation at the $3^{\prime}$ untranslated region $\left(3^{\prime} \mathrm{UTR}\right)$ of the prothrombin gene, in a group of sickle cell anemia patients from Salvador-Bahia, Brazil, in order to identify individuals at risk of developing early coagulopathies.

The study was developed in a group of 69 sickle cell patients attending the out patient clinic at the Blood Center of Bahia (HEMOBA), Salvador, Bahia, Brazil. There were $35(50.7 \%)$ males and $34(49.3 \%)$ females, with a mean age of 18.7 years (from 1 to 73 years). Approval was obtained from the Oswaldo Cruz Foundation Institutional Ethical Committee, Salvador-Bahia, Brazil. Peripheral blood samples were collected from each patient by physicians and nursing staff, into EDTA vacutainer tubes. Samples were refrigerated at $4^{\circ} \mathrm{C}$ for a maximum of 8 hours before the $\mathrm{Hb}$ profile investigation. Hemoglobin analyses were performed by cation exchange highperformance liquid chromatography (HPLC; VARIANT $\mathrm{II}^{\mathrm{TM}}$; Bio-Rad Laboratories, Hercules, CA, USA), according to the manufacturer's instructions. DNA was isolated from peripheral blood leukocytes using the GFX ${ }^{\mathrm{TM}}$ Genomic Blood DNA Purification KIT (Amersham Pharmacia Biotech Inc., Piscataway, NJ, USA), following the manufacturer's instructions. The polymerase chain reaction (PCR) and restriction fragment length polymorphism (RFLP) techniques were used to investigate the G20210A mutation of the prothrombin gene and the C677T MTHFR gene polymorphism $(7,8)$. The statistical analysis was performed using EPI Info Software version 6.04 (16). A $p$ value of less than 0.05 was considered statistically significant. 
Table 1. Prevalence of the C677T MTHFR gene polymorphism among SS patients from Salvador-Bahia, Brazil.

\begin{tabular}{lcccc}
\hline \multicolumn{4}{c}{ Frequency among SS patients } & \\
\cline { 2 - 4 } Mutations & $\begin{array}{c}\text { Wild type } \\
(\%)(n)\end{array}$ & $\begin{array}{c}\text { Heterozygotes } \\
(\%)(n)\end{array}$ & $\begin{array}{c}\text { Homozygotes } \\
(\%)(n)\end{array}$ & Total \\
\hline C677T MTHFR & $75.7(52)$ & $18.6(13)$ & $5.7(4)$ & $100.0(69)$ \\
G20210A Prothrombin & $100.0(50)$ & - & - & $100.0(50)$ \\
\hline
\end{tabular}

Of the 69 sickle cell patients diagnosed with the C677T MTHFR gene polymorphism, 13 (18.6\%) were heterozygous and four (5.7\%) homozygous. No statistically significant difference was found among the $\mathrm{T}$ allele distribution and gender, $\chi^{2}=1.81$, $p=0.405$. The G20210A prothrombin gene mutation at the $3^{\prime}$ UTR was not found in the 50 sickle cell patients investigated (Table 1).

Identifying genetic risk factors for preventive or therapeutic measures have become a common practice in clinical follow-up of sickle cell anemia patients (9). The frequency of the C677T single nucleotide polymorphism in the MTHFR gene is different among different ethnic groups (10). In Salvador, the $\mathrm{T}$ allele frequency among 843 newborns was 0.23 , with $36.2 \%$ heterozygous and 5.3\% homozygous carriers (11). In previous studies, the homozygous state for the C677T MTHFR gene polymorphism was not found among Brazilian Blacks (12) or was only found with a prevalence of $1.5 \%$ (13). Considering that the majority of the Bahian population is of African descent, the prevalence of the C677T MTHFR gene polymorphism found in the present study was considered to be high.

The G20210A mutation at the $3^{\prime}$ UTR of the prothrombin gene shows a heterogeneous worldwide geographic distribution. Our results in relation to the prothrombin gene mutation is in accordance with the low prevalence of prothrombin gene alterations in Black Africans $(14,15)$. However, we need to increase the number of patients in order to confirm the real prevalence of this gene alteration among sickle cell anemia patients from Salvador-Bahia, Brazil. Further studies about the association between this single nucleotide polymorphism and phenotype need to be done among the Bahian sickle cell anemia patients. In conclusion, the prevalence of the heterozygous and homozygous genotypes for the C677T MTHFR gene polymorphism was considered high when one takes into consideration the African origin of this population group.

\section{ACKNOWLEDGMENTS}

This study was funded in part by contract grant sponsor PAPES-FIOCRUZ; contract grant number: 0250250304; contract grant sponsor CNPq; contract grant number 521201/96-1; contract grant sponsor UNESCO/FAPESB; contract grant number 13/03 Protocol 1431030006830; contract grant sponsor Infra-Estrutura-FAPESB, and contract grant number 301/03 Protocol 1431030005540 . We are grateful to Fabíola 
Nascimento Conceição from the Oswaldo Cruz Foundation, Salvador-Bahia, Brazil, for the English review.

\section{REFERENCES}

1. Steinberg MH, Forget BG, Higgs DR, Nagel RL. Genetics of the $\beta^{S}$ gene: origins, genetic epidemiology, and epistasis in sickle cell anemia. In: Steinberg MH, Forget BG, Higgs DR, Nagel RL, eds. Disorders of Hemoglobin: Genetics, Pathophysiology, and Clinical Management. New York: Cambridge University Press, 2001;711-755.

2. Koren A, Zalman L, Levin C, Abu HM, Mader R, Shalev S. Venous thromboembolism, factor V Leiden, and methylenetetrahydrofolate reductase in a sickle cell anemia patient. Pediatr Hematol Oncol 1999; 16(5):469-472.

3. Nizankowska-Mogilnicka E, Adamek L, Grzanka P, Domagala TB, Sanak M, Krzanowski M, Szczeklik A. Genetic polymorphisms associated with acute pulmonary embolism and deep venous thrombosis. Eur Respir J 2003; 21(1):25-30.

4. Nestoridi E, Buonanno FS, Jones RM, Krishnamoorthy K, Grant PE, van Cott EM, Grabowski EF. Arterial ischemic stroke in childhood: the role of plasma-phase risk factors. Curr Opin Neurol 2002; 15(2):139-144.

5. Krieger H, Morton NE, Mi MP, Azêvedo E, Freire-Maia A, Yasuda N. Racial admixture in North-Eastern Brazil. Ann Hum Genet 1965; 29(2):113-125.

6. Azevedo ES, Alves AF, Da Silva MC, Souza MG, Muniz Dias Lima AM, Azevedo WC. Distribution of abnormal hemoglobins and glucose-6-phosphate dehydrogenase variants in 1200 school children of Bahia, Brazil. Am J Phys Anthropol 1980; 53(4):509-512.

7. Poort SR, Rosendaal FR, Reitsma PH, Bertina RM. A common genetic variation in the $3^{\prime}$ untranslated region of the prothrombin gene is associated with elevated plasma prothrombin levels and an increase in venous thrombosis. Blood 1996; 88(10):3698-3703.

8. Frosst P, Blom HJ, Milos R. A candidate genetic risk factor for vascular disease: a common mutation in methylenetetrahydrofolate reductase. Nat Genet 1995; 10(1):111-113.

9. Adams GT, Snieder H, McKie VC, Clair B, Brambilla D, Adams RJ, Kutlar F, Kutlar A. Genetic risk factors for cerebrovascular disease in children with sickle cell disease: design of a case-control association study and genomewide screen. BMC Med Genet 2003; 4(1):6-15.

10. Fletcher O, Kessling AM. MTHFR association with arteriosclerotic vascular disease. Hum Genet 1998; 103(1):11-21.

11. Couto FD, Adorno EV, Menezes JF, Moura Neto JP, Rego MA, dos Reis MG, Goncalves MS. C677T polymorphism of the MTHFR gene and variant hemoglobins: a study in newborns from Salvador, Bahia, Brazil. Cad Saude Publica 2004; 20(2):529-533.

12. Franco RF, Araújo AG, Guerreiro JF, Elion J, Zago MA. Analysis of the $677 \mathrm{C} \rightarrow \mathrm{T}$ mutation of the methylenetetrahydrofolate reductase gene in different ethnic groups. Thromb Haemost 1998; 79(1):119-121.

13. Arruda VR, Siqueira LH, Gonçalves MS, von Zuben PM, Soares MC, Menezes R, 
Annichino-Bizzacchi JM, Costa FF. Prevalence of the mutation C677T in the methylene tetrahydrofolate reductase gene among distinct ethnic groups in Brazil. Am J Med Genet 1998; 78(4):332-335.

14. Rosendaal FR, Doggen CJ, Zivelin A, Arruda VR, Aiach M, Siscovick DS, Hillarp A, Watzke HH, Bernardi F, Cumming AM, Preston FE, Reitsma PH. Geographic distribution of the $20210 \mathrm{G} \rightarrow \mathrm{A}$ prothrombin variant. Thromb Haemost 1998; 79(4):706-708.

15. Dilley A, Austin H, Hooper WC, El-Jamil M, Whitsett C, Wenger NK, Benson J, Evatt B. Prevalence of the prothrombin $20210 \mathrm{G} \rightarrow \mathrm{A}$ variant in Blacks: infants, patients with venous thrombosis, patients with myocardial infarction, and control subjects. J Lab Clin Med 1998; 132(6):452-455.

16. Dean AG, Dean JA, Coulombier D. Epi Info, Version 6: A Word Processing Program for Public Health on IBM-compatible Microcomputers. Atlanta: Center for Disease Control and Prevention, 1994.

Received January 16, 2004

Accepted March 8, 2004 
Copyright of Hemoglobin is the property of Marcel Dekker Inc. and its content may not be copied or emailed to multiple sites or posted to a listserv without the copyright holder's express written permission. However, users may print, download, or email articles for individual use. 